\title{
College Students' Motivation after Teaching Using Sport Education Season
}

\author{
Agi Ginanjar*, Mochamad Zakky Mubarok, Dicky Oktora Mudzakir \\ Department of Physical Education, Health and Recreation STKIP Nahdlatul Ulama Indramayu, Indramayu, Indonesia
}

Received April 24, 2021; Revised June 15, 2021; Accepted July 16, 2021

\begin{abstract}
Cite This Paper in the following Citation Styles
(a): [1] Agi Ginanjar, Mochamad Zakky Mubarok, Dicky Oktora Mudzakir , "College Students' Motivation after Teaching Using Sport Education Season," International Journal of Human Movement and Sports Sciences, Vol. 9, No. 4A, pp. 1 - 7, 2021. DOI: 10.13189/saj.2021.091301.
\end{abstract}

(b): Agi Ginanjar, Mochamad Zakky Mubarok, Dicky Oktora Mudzakir (2021). College Students' Motivation after Teaching Using Sport Education Season. International Journal of Human Movement and Sports Sciences, 9(4A), 1 - 7. DOI: $10.13189 /$ saj.2021.091301.

Copyright $\bigcirc 2021$ by authors, all rights reserved. Authors agree that this article remains permanently open access under the terms of the Creative Commons Attribution License 4.0 International License

\begin{abstract}
College Sports or Physical Education Teacher Education programs must be able to provide a learning experience that can motivate college students and also equip them to become sports teachers in the future. Motivation has an important function because it can determine the efforts of college students in the learning process and teaching process later. Therefore, we need a learning strategy that can provide a learning experience with motivation in the learning process. Sport Education (SE) can provide all of that. This study aims to see the level of college students' motivation after participating in the SE season according to their role in SE. The research method used descriptive approach. Participants were 35 college students in the eastern part of West Java Province, Indonesia. The instrument used in this study was the Learning Self-Regulation Questionnaire (SRQ-L). The data analysis technique used descriptive statistics. The results showed that the level of motivation of the coaches compared to all other roles and the roles involved in the team have a higher level of motivation than the roles involved out of the team. It is necessary to investigate what sports orientation underlies college students with the existence of competition activities in SE and a deeper study of research instruments.
\end{abstract}

Keywords College Students, Motivation, Sport Education

\section{Introduction}

Motivation has a very important function because it can determine students' efforts in the learning process [1]. Students who have high motivation do better than students who have low motivation [2]. The problem faced is that students' intrinsic motivation in the physical education (PE) learning process feels that PE is not important for their education [3]. Furthermore, schools that do not comply with the physical activity guidelines have decreased motivation in learning PE [4]. College, especially those related to sports teacher education programs or PE in Indonesia, must be able to provide college students with a learning experience that can provide motivation, because in PE learning there are still many students faced with a lack of motivation. Effective professional development may have a positive effect on teacher knowledge and motivation as well as improve student learning [5] and it is also important to avoid negative physical activity course experiences in higher education [6]. Therefore, it is necessary to have a learning strategy that can motivate college students to participate in the learning process and also to equip them to become PE teachers later.

Sport Education (SE) is a pedagogical model based on the concept of small study groups that work together in a team to achieve success according to the role in the team in following the learning season [7]. SE is a curriculum model that can be developed extensively by teachers for use in various forms of sports activities [8]. Students who are involved in SE will become literate, competent, and 
enthusiastic in sports activities [9], through six characteristics such as seasons, affiliation, formal competition, culminating events, keeping records, and festivity [9].

$\mathrm{SE}$ is a curriculum model that can be used in the learning process to increase motivation in following the learning process. By using $\mathrm{SE}$, the intrinsic motivation inherent in play is a sufficient condition to lift and sustain the spirit of sports inside and outside of learning [10]. It has been reported that in the learning process using SE student motivation increases [11]. Students provide high motivation such as enjoying learning and other psychosocial aspects while participating in SE [12]. Using SE can maintain existing levels of motivation and increase motivation $[13,14]$. SE can lead to greater autonomic motivation [15]. Moreover, SE provides an increase in physical activity in amotivated students [16]. As previously explained, SE has an impact on learning, plus it has been found that motivation theory has a positive effect on SE [17]. Moreover, SE is relatively consistent in promoting motivational outcomes regarding gender, grade level, exercise, and motivation profile [17].

Motivation theory has been developed and used in research using SE; one of which is self-determination theory (SDT) [18]. Research on SE using SDT was first carried out by [11], which then motivated a positive influence on SE in learning [19]. SDT differentiates types of behavior regulation. SDT is a series ranging from intrinsic motivation (intrinsic regulation), extrinsic motivation (external regulation, introjected regulation, identified regulation, and integrated regulation), to the absence of motivation / amotivation (non-regulation) [20]. Intrinsic motivation comes from autonomous behavior or motivation from within. Extrinsic motivation comes from less autonomous behavior so that it is internalized and integrated so that it becomes the basis for autonomic behavior. Meanwhile, the absence of motivation / amotivation means not motivated at all both intrinsically and extrinsically.

Regarding SE and motivation, SE with motivation has been fully discussed in secondary schools [17]. However, no one has investigated the motivation of college students using SE. Because the new findings are limited to SE intervention for one semester, it can improve student learning and keep students motivated in a higher education environment [6]. Therefore, it is necessary to look at the level of motivation of college students in sports and PE programs by using SE as a prospective PE teacher in order to have a learning experience that can keep students motivated, so that it can be useful for college students later in their professional development as PE teachers in the future. It is in line with this because one of the motivations for entering a sports teacher education program at a university upon graduation is to become a teacher who 'teaches proper sports' [21]. University students view sports programs positively when teachers are encouraging and motivating [22].

\section{Methods}

The research method used in this study was descriptive quantitative approach. Participants were 35 college students (33 boys and two girls) in the eastern part of West Java Province, Indonesia, who were involved in the SE futsal season. In contrast to the SE suggested by [7], because participants involved research college students to focus more on roles according to the roles they got in accordance with the original in official competitions. In terms of outline, the coach has a role to train and prepare players for the competition. The manager is in charge of preparing the needs and equipment of the team. The referee makes the rules for the match up to the form of competition that will be used. The record keeper is in charge of creating match sheets, line-up sheets for players in competition matches, and recording the results of competition matches. Publications record all activities such as real reporters so that the event runs lively and announcers during matches. So during the research, each role was focused on its respective task. The division of roles according to the characteristics of the $\mathrm{SE}$ was divided into three teams (team $\mathrm{A}$, team $\mathrm{B}$, team $\mathrm{C}$ ). Each team consisted of one coach, one manager, and seven players including the team captain. So that the role of coaches, managers, and players means being involved in the team role. Two college students acted as referees, three as match recorders, and three as publications which means they are roles involved out of the team.

The selection of coaches and managers is based on the agreement that the college students involved are college students who have good futsal skills and also those college students are members of the college futsal team who often participate in futsal competitions. Then the referee was also chosen based on an agreement because the two referees involved had served as futsal referees in several futsal competitions. The marginalized thing occurred when the match recorders were selected, where of the three match recorders, two of them were women. The role of publication is selected based on the volunteerism of college students to get that role. Meanwhile, the distribution of players into each team is done by drawing based on the agreement of all college students. In addition, the participants involved have had learning experiences regarding the lecture model of teaching procedures that follow $[23,24]$, such as: direct instruction (DI), personalized system for instruction (PSI), student team achievement division (STAD), team games tournament (TGT), jigsaw, group investigation (GI), and, peer.

The SE season consists of 15 lessons divided into three phases: skill / tactical development, inter / intra team games with practices, and postseason [16] using a 
combination of direct instruction, cooperative, and peer models [25] with model verification using a combined check sheet at two points in time: planning and implementation [26-28]. The results of the inter-rater reliability value were 0.94 in planning and 0.73 in implementation using two experts with expertise in the model of teaching.

The instrument used the Learning Self-Regulation Questionnaire (SRQ-L) with two subscales: autonomous regulation and controlled regulation adapted from SRQ-L in a medical school course in organ systems for 14 test items [29] and organic chemistry as many as 12 test items [30]. Validation was carried out on college students in sports and PE programs who had studied SE as many as 72 college students in the eastern part of the province of West Java Indonesia using 14 test items and after passing several validation stages ten test items were used. Validation was analyzed using confirmatory factor analysis using the help of IBM SPSS Amos 22 with the results of CMIN $/ \mathrm{DF}=1.92<2$. RMSEA $=0.064$ between $0.05-0.08$ with NFI, PNFI, CFI, IFI, RFI, GFI, AGFI with each of The indicated $0.83,0.62,0.91,0.91,0.77$, 0.86 , and 0.78 were accepted so that the structural equation modeling was good with reliability values in the autonomous regulation of 0.86 and controlled regulation of 0.78 . The analysis technique uses descriptive statistics calculated with the help of Microsoft Excel 2019.

\section{Results}

The difference in the mean motivation level of college students after participating in the SE futsal season according to the role in SE characteristics can be seen in Figure 1. Meanwhile, the difference in the mean motivation level of college students involved in the team (coach, manager, player) and outside the team (referees, publications, match recorders, and publications) can be seen in Figure 2, and the difference in the mean motivation level of college students involved in the team of three teams can be seen in Figure 3.

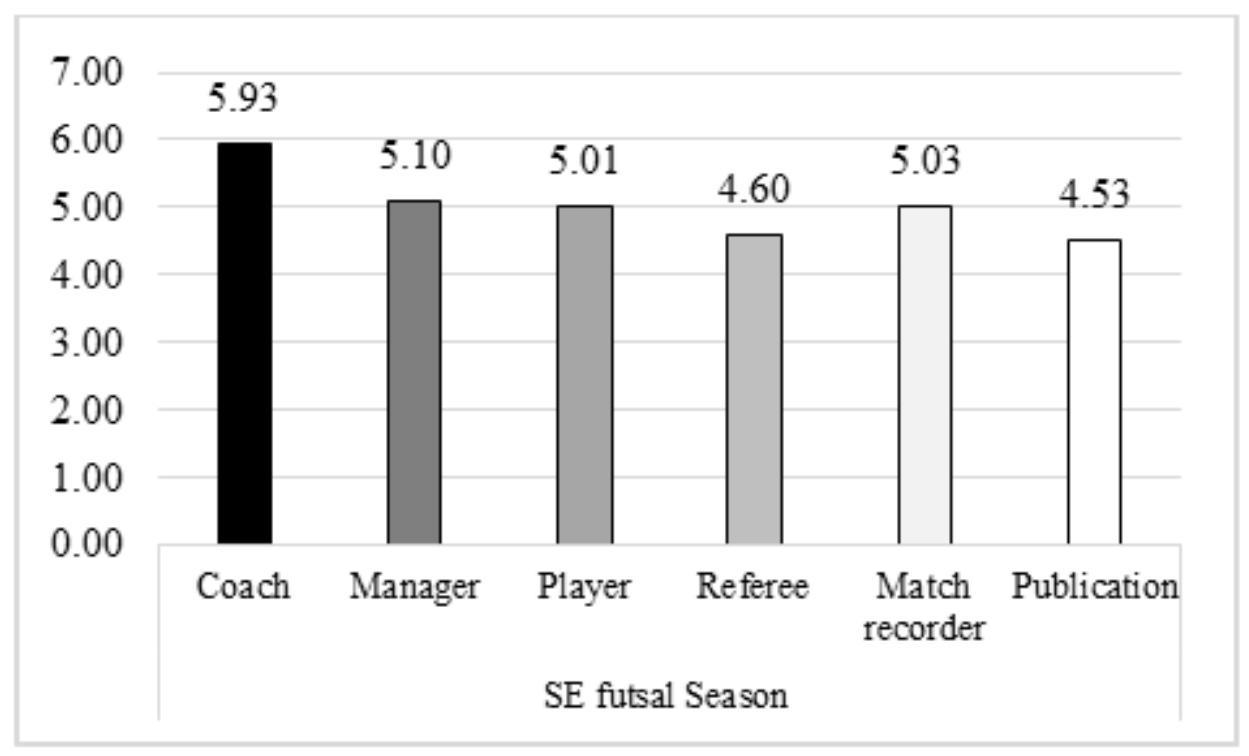

Figure 1. Differences in the mean motivation of college students according to roles in the characteristics of SE 


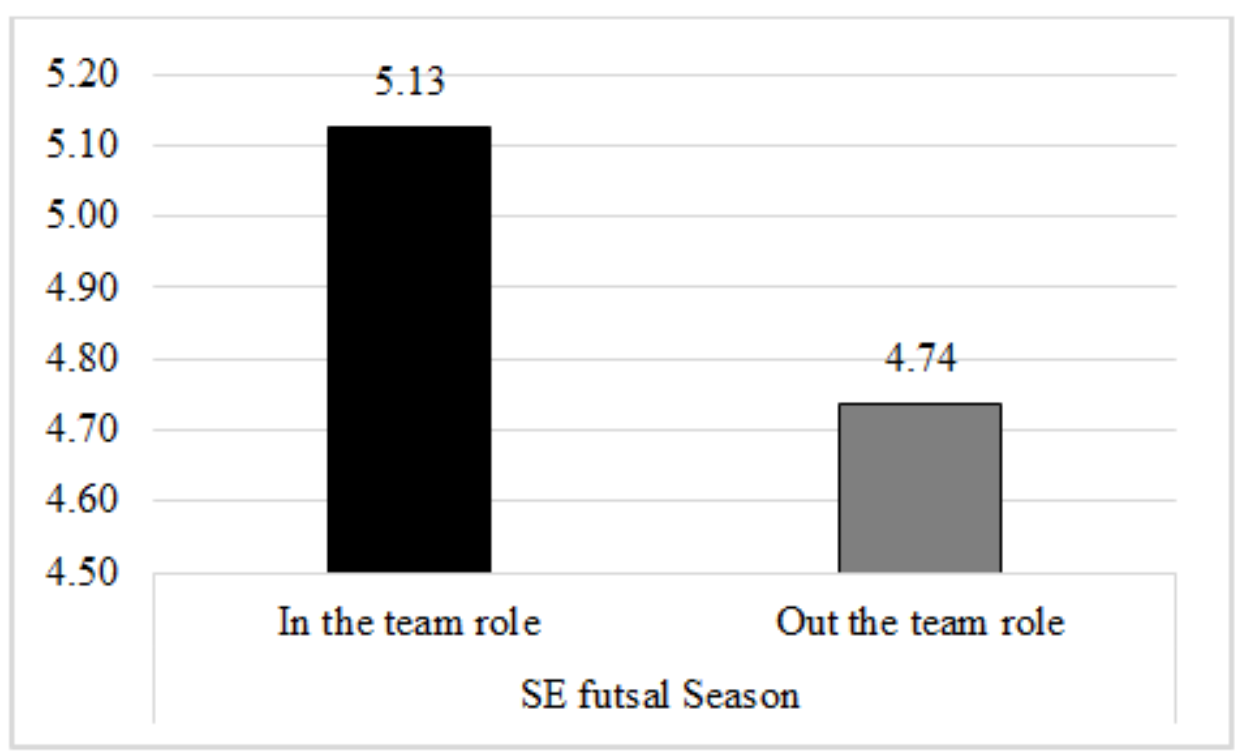

Figure 2. Differences in the average motivation of college students who are involved in the team role and out the team role

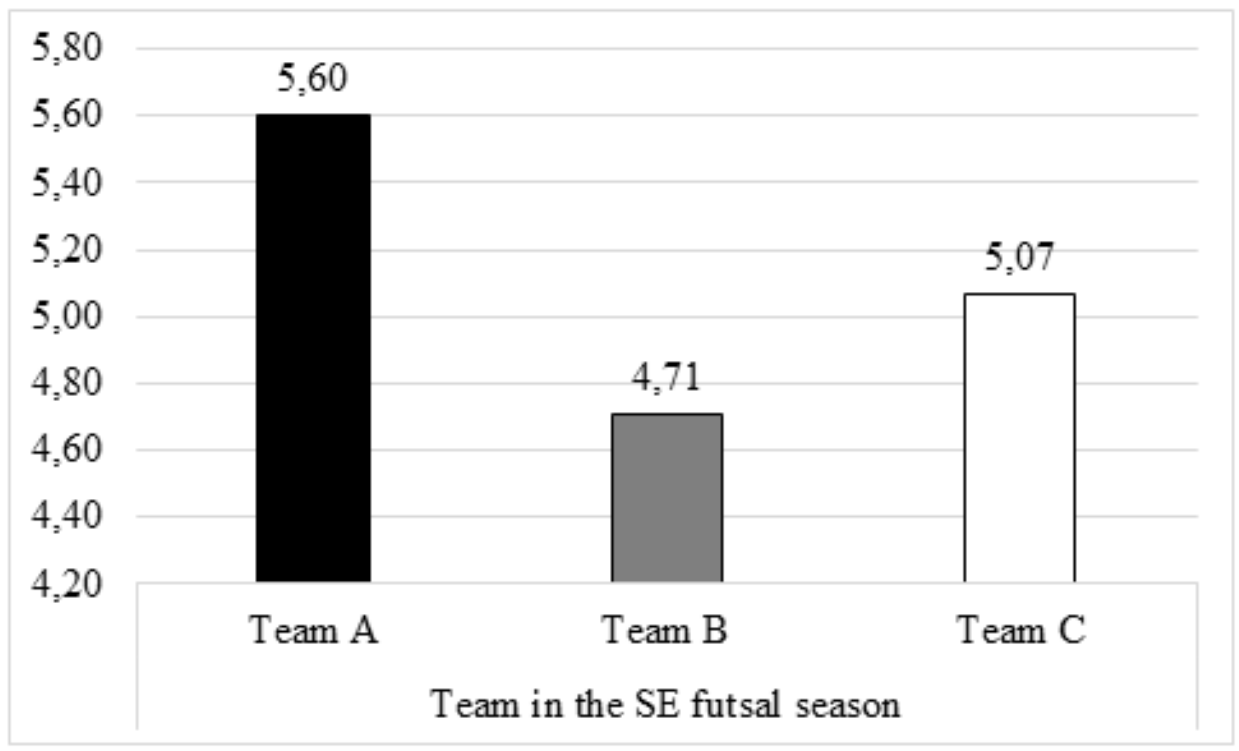

Figure 3. Differences in the average motivation of college students involved in three different teams

From the results of data analysis, it was obtained that the mean roles involved in SE futsal in research such as coaches, managers, players, referees, match recorders, and publications were respectively 5.93, 5.1, 5.01, 4.6, 5.03, and 4.53. The mean difference between in-team roles and out-of-the-team roles is 5.13 and 4.74 , respectively. The mean differences involved in the three different teams team $\mathrm{A}$, team $\mathrm{B}$, and team $\mathrm{C}$ were $5.6,4.71$, and 5.07, respectively.

\section{Discussion}

From the findings, the coach's role provides the greatest motivation among all the roles involved. This is in accordance with what happened that every coach must be able to provide motivation to his team to be able to fight together for success in following the SE season. When teams work together, they must develop a sense of affiliation which will gradually lead to higher team motivation and the team coach must always act in a way that allows and empowers the team to complete tasks and work together well [7]. As has been explained that the role of the coach was chosen because these three coaches have the ability to play futsal well and as members of the college futsal team who often participate in futsal competitions by looking at the level of motivation obtained, this might be a solution to using SE in college related to the effectiveness of student coaches. in facilitating peer motor skills [31]. However, the development of content knowledge [31] and some student coaches may be quality players, but cannot provide 
quality practice for their students [32] and have not been confirmed in this study so that this can be used as a research that further. In accordance with the statement that it is expected that pre-service teachers have the necessary pedagogy and subject matter knowledge is needed to perform the role of coach [33].

Interesting findings occur even though this study indicates a coach who has good futsal skills can facilitate the skills of his friends as players despite the fact that the trainer has been given a program using DI, cooperative, and peer. In the field implementation they did not use the model they had mastered the results of their learning experience using the model of teaching, so that coaches concentrate more on the skills of their players, in line with a statement that student coaches only maintain consistent teaching and learning for tasks that focus on improving skills or tactical-based tasks [34]. Student coaches only maintain consistent teaching and learning for tasks that focus on improving skills or tactical-based tasks [34]. It is therefore necessary to pay attention to the frequency of problematic breaches in didactic contracts that occurred during the elaboration of the coach to the players in order to provide the need for more effective trainer preparation to communicate content in the overall peer teaching task of pedagogy needed to convey the content of the assignment [34] and in order to give "a little" freedom for the trainer to develop the content but still stick to what models are used in the learning. In line with this, the nature of the relationship between teacher and student coaches and effective learning strategies that can be used during $\mathrm{SE}$ can be of significant value for model practitioners [35].

Likewise, manager coaches are ranked second after coaches in terms of motivation results. The coach and manager are inseparable things in a team in the SE season; they will motivate each other to achieve success following the SE season. In line with this, the role of students as coaches and managers is very important as coaches work with teammates such as providing training, resolving conflicts, and preparing players for competition. Meanwhile, the manager ensures all the needs and equipment that will be used in both training and competition [7].

One of the most interesting findings is on the role of match recorder consisting of three people ( 2 girl and 1 boy). This is a marginalized role in which the two college students are placed as match recorders during the initial role selection before the SE season starts. The reason is because they do not like futsal and futsal is a masculine sport with lots of physical contact. However, the findings of motivation shows that the match recorder is ranked third among all roles. It was added that a male college student in this role enjoyed his role as match recorder. This could be due to the background of this male student as a committee in sports competitions as a match recorder.

The motivation to use SE is closely related to the team involved in the SE season. Teams learn, practice, and compete together, because competition is very important for the success of SE which will provide motivation and can enhance learning [7]. However, it needs to be kept in mind that being a winner is not the main goal of SE, but the competition must be fair and even [7]. This is the reason why the role of college students who are involved in the role of higher education has higher motivation than the role of college students who are involved in out the role. However, these findings need to be studied more deeply because these findings have a different number of participants. The roles of college students involved in the team were 27 and the roles of college students who were involved out the team were eight.

Although SE's main goal is not to win matches in a competition, SE teams learn, practice, and compete together, because competition is very important for the success of SE [7]. Consciously or unconsciously, each student will show their best performance to compete for the best results [36]. These findings support that achievement in sports competition (sports orientation) depends on goal orientation $[37,38]$. The findings of this study are that the results of a sports competition using futsal, team $\mathrm{C}$ with motivation below team A's motivation to win this championship in the final and team B lose in the preliminary round, which in this study uses a roundrobin system with first and second ranks entitled following the finals. The preliminary round is carried out in two rounds so that all the teams compete four times. The final results of the standings table also show that team C topped the first rank followed by team A and team C. Overall, in line with this, motivation shows a high level of quality for most players to train with friends [39]. However, no further investigation has been carried out which orientation underlies the three teams in the underlying sports orientation.

From the overall findings obtained in this study, it is necessary to study further related to the motivation of college students in participating in the SE season. In addition, it is also necessary to study physical activity in fulfilling the recommendations for physical activity of college students in participating in sports [40]. It is different from SE in PE in schools which can use SRQ-A in PE learning which has been widely used in various studies [41]. The SRQ-L instrument needs to be studied more deeply because the validation still adapts the words of the results of the SRQ-L in a medical school course in organ systems $[29,30]$ and this instrument in general has not explored the characteristics contained in SE.

\section{Conclusions}

Overall from the findings and discussions that have been presented, it is shown that the level of motivation of the coaches compared to all other roles and the roles 
involved in the team have a higher level of motivation than the roles involved out of the team.

\section{Acknowledgments}

The authors would like to thank all college student participants who have helped the completion of this research.

\section{REFERENCES}

[1] Ginanjar A. The Influence of Inquiry Method in Motivating the SMP' Student. J Kependidikan 2015; 45: 123-9. https://doi.org/http://dx.doi.org/10.21831/jk.v45i2.7 489.

[2] Hidayat Y. Psikologi Olahraga. Bandung: Wali Artika; 2010.

[3] Richards KAR, Levesque-Bristol C. Student Learning and Motivation in Physical Education. Strategies 2014;27:43-6. https://doi.org/10.1080/08924562.2014.879431.

[4] Ntoumanis N, Standage M. Motivation in physical education classes: A self-determination theory perspective. Theory Res Educ 2009;7: 194-202. https://doi.org/10.1177 $/ 1477878509104324$.

[5] Armour KM, Yelling MR. Continuing Professional Development for Experienced Physical Education Teachers: Towards Effective Provision. Sport Educ Soc 2004;9:95-114. https://doi.org/10.1080/135733204200017 5836.

[6] André MH, Hastie P. Sport Education in a Higher Education physical activity course. Eur J Phys Educ Sport Sci 2017;3:22-35. https://doi.org/10.5281/zenodo.583365.

[7] Siedentop D, Hastie PA, Mars H van der. Complete Guide to Sport Education. Champaign: Human Kinetics; 2011.

[8] Ginanjar A. Implementasi Praktis Sport Education Model. Indramayu: Program Studi Pendidikan Jasmani Kesehatan dan Rekreasi STKIP Nahdlatul Ulama Indramayu; 2019.

[9] Siedentop D. Sport education: quality PE through positive sport experiences. Champaign: Human Kinetics; 1994.

[10] Oslin J. Sport education: Cautions, considerations, and celebrations. J Teach Phys Educ 2002;21:419-26. https://doi.org/10.1123/jtpe.21.4.419.

[11] Wallhead TL, Ntoumanis N. Effects of a Sport Education Intervention on Students' Motivational Responses in Physical Education. J Teach Phys Educ 2004;23:4-18. https://doi.org/10.1123/jtpe.23.1.4

[12] Perlman D, Karp GG. A self-determined perspective of the Sport Education Model. Phys Educ Sport Pedagog 2010;15:401-18. https://doi.org/10.1080/17408980903535 800 .

[13] Barbosa Porcellis da Silva R, Marques AC, Reichert FF. Objectively measured physical activity in Brazilians with visual impairment: description and associated factors. Disabil Rehabil 2017;8288:1-7.https://doi.org/10.1080/096 38288.2017 .1327984 .

[14] Spittle M, Byrne K. The influence of Sport Education on student motivation in physical education. Phys Educ Sport Pedagog 2009;14:253-66.

[15] Gil-arias A, Harvey S, Carceles A, Praxedes A, Villar F Del. Impact of a hybrid TGfU-Sport Education unit on student motivation in physical education. PLoS One 2017;12:1-17. https://doi.org/10.1371/journal.pone.01798 76.

[16] Perlman D. The influence of the Sport Education Model on a motivated students' in-class physical activity. Eur Phys Educ Rev 2012; 18:335-45. https://doi.org/10.1177/13563 $36 \mathrm{X} 12450795$.

[17] Chu TL (Alan), Zhang T. Motivational processes in Sport Education programs among high school students: A systematic review. Eur Phys Educ Rev 2018; 24:372-394. https://doi.org/10.1177/1356336X17751231.

[18] Deci EL, Ryan RM. Intrinsic Motivation and SelfDetermination in Human Behavior. New York: Plenum Press; 1985.

[19] Hastie PA, de Ojeda DM, Calderón A. A review of research on sport education: 2004 to the present. Phys Educ Sport Pedagog 2011;16:103-32. https://doi.org/10.10 80/17408989.2010.535202

[20] Ryan RM, Deci EL. Self-determination theory and the facilitation of intrinsic motivation, social development, and well-being. Am Psychol 2000;55:68-78. https://doi.org/10 .1037//0003-066x.55.1.68.

[21] Chen YC, Curtner-Smith M. Hegemonic masculinity in sport education: Case studies of experienced in-service teachers with teaching orientations. Eur Phys Educ Rev 2013;19:360-80.https://doi.org/10.1177/1356336X134956 31

[22] Jenkins JM, Alderman BL. Influence of sport education on group cohesion in university physical education. $\mathrm{J}$ Teach Phys Educ 2011;30:214-30.https://doi.org/10.1123/jtpe.30 .3.214.

[23] Metzler MW. Instructional Models for Physical Education (2nd ed.). Scottsdale, Arizona: Holcomb Hathaway; 2005.

[24] Metzler MW. Intructional Models for Physical Education. Massachusetts: Allyn and Bacon; 2000.

[25] Ginanjar A, Suherman A, Juliantine T, Hidayat Y. Sports Orientation during Learning Team or Individual Sports using A Sport Education Model. Cakrawala Pendidik 2019;38:377-86. https://doi.org/10.21831/cp.v38i2.24021.

[26] Ko B, Wallhead T, Ward P. Chapter 4: Professional development workshops - What do teachers learn and use? J Teach Phys Educ 2006;25:397-412. https://doi.org/10.1123/jtpe.25.4.397.

[27] Hastie PA, Sinelnikov OA. Russian students ' participation in and perceptions of a season of Sport Education. Eur Phys Educ Rev 2006;12:131-50. https://doi.org/10.1177/1 356336 X06065166.

[28] Perlman D. Change in Affect and Needs Satisfaction for 
Amotivated Students within the Sport Education Model. J Teach Phys Educ 2010;29:433-45. https://doi.org/10.1123/jtpe.29.4.433.

[29] Williams GC, Deci EL. Internalization of Biopsychosocial Values by Medical Students: A Test of Self-Determination Theory. J Pers Soc Psychol 1996;70:767-79.

[30] Black AE, Deci EL. The effects of instructors' autonomy support and students' autonomous motivation on learning organic chemistry: A self-determination theory perspective. Sci Educ 2000;84:740-56.

[31] Alexander K, Luckman J. Australian Teachers \& iacute; Perceptions and Uses of the Sport Education Curriculum Model. Eur Phys Educ Rev 2001;7:243-67. https://doi.org/10.1177/1356336X010073002.

[32] Hastie PA. An Ecological Analysis of a Sport Education Season. J Teach Phys Educ 2000;19:353-73. https://doi.org/10.1123/jtpe.19.3.355.

[33] Deenihan JT, McPhail A, Young A-M. 'Living the curriculum': Integrating sport education into a Physical Education Teacher Education programme. Eur Phys Educ Rev 2011;17:51-68. https://doi.org/10.1177/1356336X11 402262.

[34] Wallhead T, O'sullivan M. A didactic analysis of content development during the peer teaching tasks of a Sport Education season. Phys Educ Sport Pedagog 2007;12:22543. https://doi.org/10.1080/17408980701610177.

[35] Sinelnikov OA, Hastie PA. A motivational analysis of a season of Sport Education. Phys Educ Sport Pedagog 2010;15:55-69. https://doi.org/10.1080/17408980902729362.

[36] Ginanjar A, Suherman A, Juliantine T, Hidayat Y. Competitive in Physical Education Using Sports Education Model. 3rd Int. Conf. Sport. Sci. Heal. Phys. Educ., Bandung: FPOK UPI Bandung; 2018.

[37] Farshad T, Jasem M, Mohammad M. Validation of an Instrument for Measuring Athletes' Sport Orientation in Iranian Martial Artists Community. Middle-East J Sci Res 2013;18:738-43.

https://doi.org/10.5829/idosi.mejsr.2013.18.6.75140.

[38] Sheikh M, Afshari J, Sheikh H. Comparing sport orientation between individual and team sports and its relation to sport participation motivation. Am J Sci Res 2011;30:28-35.

[39] Nasiruddin MN, Fauzee MSO, Sin I, Omar MN. The motivation of football players: The impact of coach leadership style in malaysian sports schools. Int $\mathrm{J}$ Hum Mov Sport Sci 2020; 8(4): 124-133. DOI: 10.13189/saj.2020.080404.

[40] Razak MRA, Ismail E, Bakar AYA. Profiling of physical activity, health fitness (Vo2max), body composition, and dietary intake among malaysian university students: A case study. Int J Hum Mov Sport Sci 2020; 8(6): 413-420. DOI: 10.13189/saj.2020.080613.

[41] Goudas M, Biddle S, Fox K. Perceived locus of causality, goal orientations, and perceived competence in school physical education classes. Br J Educ Psychol 1994; 64:453-63. https://doi.org/10.1111/j.2044- 8279.1994.tb01 116.x. 